\title{
Sponges Revealed: A Synthesis of Their Overlooked Ecological Functions Within Aquatic Ecosystems
}

\author{
Mainah Folkers and Titus Rombouts
}

\begin{abstract}
While sponges are the oldest still living multicellular animals on this planet and omnipresent within aquatic ecosystems, they have not been studied nearly as much compared to the recognized ecosystem drivers in coral reefs: corals, algae, and fish. We therefore want to take this opportunity to illustrate the diversity, functionality, and sheer survivability of these ancient animals. Beyond its multitude of external shapes and colors, sponges hold a unique internal aquiferous system. This system of afferent and efferent canals is intricately linked to supply its key function as a filter feeder. By filtering both particulate and dissolved material, sponges fill a niche in nutrient cycling. Moreover, the survivability of sponges is demonstrated in the variety of habitats it resides in; from freshwater canals to polar deep seas. In formerly uninhabitable environments, sponges can potentially create biodiversity hotspots by providing habitat complexity and shelter from predators. This review will give insight into the early life history, morphology, diet, and reproduction of sponges. Furthermore, it is imperative to consider their function as habitat facilitator, nutrient cycler, and, last but not the least, their potential for future pharmaceuticals. The emphasis in the proceedings has been specifically put on the role of sponges as nutrient cycler as they play a role in the three essential elements: carbon, nitrogen, and phosphorous. With all this in mind, it should be clear that even though sponges are relatively overlooked marine invertebrates, they should be studied similarly to corals and respected as a key ecosystem driver in novel and established environments.
\end{abstract}

Mainah Folkers and Titus Rombouts contributed equally to this chapter.

M. Folkers $(\bowtie) \cdot$ T. Rombouts $(\bowtie)$

Institute for Biodiversity and Ecosystem Dynamics, University of

Amsterdam, Amsterdam, The Netherlands
Keywords

Porifera $\cdot$ Filter feeders $\cdot$ Nutrient cycling $\cdot$ Habitat

facilitation $\cdot$ Marine natural products

\subsection{Introduction}

Ever since marine research has been documented several hundreds of years ago, we usually consider coral reefs as iconic examples of biological hotspots. These reefs have provided potential services to the ecosystem, among them are their services for early humans to maintain nutritional uptake. We have typically considered coral reefs to consist of three big ecosystem drivers: corals, algae and fish. Yet, within these coral reefs lie a less familiar but equally important builder and energy conveyer: sponges. Slowly, recognition develops that sponges are key ecosystem engineers. They have the capacity to retain nutrients and transform them into a bio-available form back into their surrounding habitat while providing protection for motile fauna. In fact, on Caribbean coral reefs, sponges usually show a higher diversity and higher abundance compared to corals (Diaz and Rützler 2001).

However, apart from these iconic coral reefs, there is a multitude of habitats in which sponges thrive (Gili and Coma 1998). Habitats can range from the deep sea to turbulent freshwater canals among cities. Within these various habitats, sponges perform important so-called benthic-pelagic coupling, which is a crucial ecosystem service to recycle pelagic nutrients toward the benthos that would otherwise be unavailable to higher trophic levels (Griffiths et al. 2017). For example, the Caribbean giant barrel sponge Xestospongia muta shows a large role in the carbon transfer from the water column to the benthos (McMurray et al. 2017). Moreover, it could be suggested that, in previously uncolonized marine environments, sponges are among the first settlers creating a three-dimensional habitat, allowing benthic ecosystem 
hotspots to develop. However, research is needed to elucidate the potential functional role of sponges as ecosystem engineers.

Apart from the potential functional role sponges fulfill, there is also a wide debate on the phylogenetic relationship among major animal lineages; yet recent research has shown through genomic data that sponges rather than the proposed comb jellies (Dunn et al. 2008) can be interpreted as the sister group to the remaining animals (Nakanishi et al. 2014; Pisani et al. 2015). Considering sponges could be among the first multicellular animals, they are remarkable study objects with respect to evolution. Unlike cnidarians and ctenophores, sponges lack a nervous system but do allow cells to move through layers and accordingly change function (Nakanishi et al. 2014). These characteristics make sponges a unique animal filling niches within the aquatic environment. Yet research regarding sponges until the year 2017 is substantially lower (637 publications) compared to corals (1590 publications) (Fig. 9.1). However, the research regarding sponges is on the rise with projects such as the "EU horizon 2020"-funded SponGES. We hope to appeal to more funding projects in the future to be able to investigate sponges at similar levels to corals.

This review is arranged in four sections. The first section will draw the attention to sponges' life history, morphology, diet, and reproduction. All these components add to the special position of sponges related to other marine animals. The second section focuses on how sponge morphology plays a role in facilitating habitats for other life forms such as fish, crustaceans, and other invertebrates. Within these habitats, sponges play an important role in the cycling of nutrients to make carbon, nitrogen, and phosphorous bioavailable, which is argued in the third section. Finally, the fourth section will

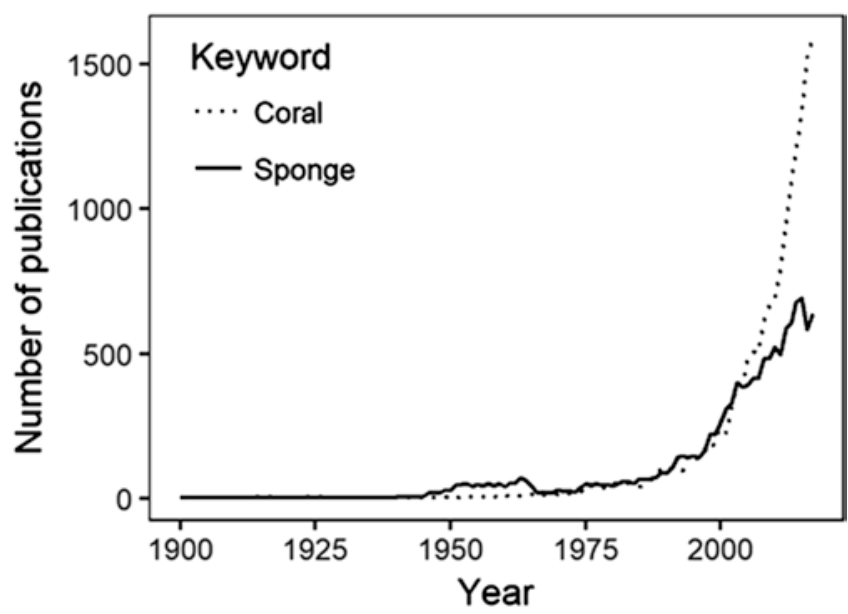

Fig.9.1 Annual number of scientific publications on the PubMed database including the words "coral" (dotted line) or "sponge" (solid line) in the publication title or as a keyword from 1900 to 2017 dive into the human-related prospects of sponges, in both their physical form and at a molecular level as marine natural products valuable to the pharmaceutical industry.

\subsection{Sponge Characteristics}

\subsubsection{History and Phylogeny}

Before we can understand the potentially important ecosystem functions of sponges as filter feeders, we need to establish a rudimentary familiarity with the history and morphology of sponges. Sponges (Porifera) have diverged earliest from within the metazoans around 600 million years ago and are one of the most diversified invertebrate phyla present in both the marine ( 8000 species) and freshwater ( $\sim 50$ species) environment (van Soest et al. 2018). Yet discussion remains if sponges, rather than ctenophores, are considered the sister group to all the remaining animals (Pisani et al. 2015; Adamska 2016; Simion et al. 2017). There are three classes of sponges which, in general, display bathymetric differences in abundance: Calcarea, Demospongiae, and Hexactinellida (Fig. 9.2) (Reid 1968). Furthermore, later research has shown sponges differ over depth in body size and shape in shallow (Bell and Barnes 2000) and deep areas (Maldonado and Young 1996).

Calcarea or calcareous sponges are restricted to shallow environments where it is least demanding to produce calcium carbonate (Vacelet 1988). Demospongiae constitute to about $90 \%$ of all sponge species and live in the widest range of habitats (Zenkevich et al. 1960). From the epipelagic until the bathypelagic zone, they thrive in both freshwater and marine environments, under various shapes and sizes (van Soest et al. 2018). Finally, Hexactinellida or glass sponges are the least flexible species. They possess a net of amoebocytes where the epidermal cells would be in other sponge classes. Their cells are interspersed with glass spicules protruding on the outside, which makes them a very rigid class (Barnes 1982). This class is present in polar regions and ocean depths of the abyssal pelagic zone. All three classes have hard skeletal elements called spicules to support their body. The spicules of Calcarea contain calcium carbonate, while the latter two are made up of hydrated silicon dioxide. Recently, the fourth class of sponges has been recognized to be phylogenetically well distinct from their closest relative Demospongiae: Homoscleromorpha (Gazave et al. 2012). They display a relatively simple body structure and with 184 species constitute to only $2 \%$ of the sponge species recorded (Hooper and van Soest 2002; van Soest et al. 2018). Therefore, our focus will remain on the three aforementioned classes. 


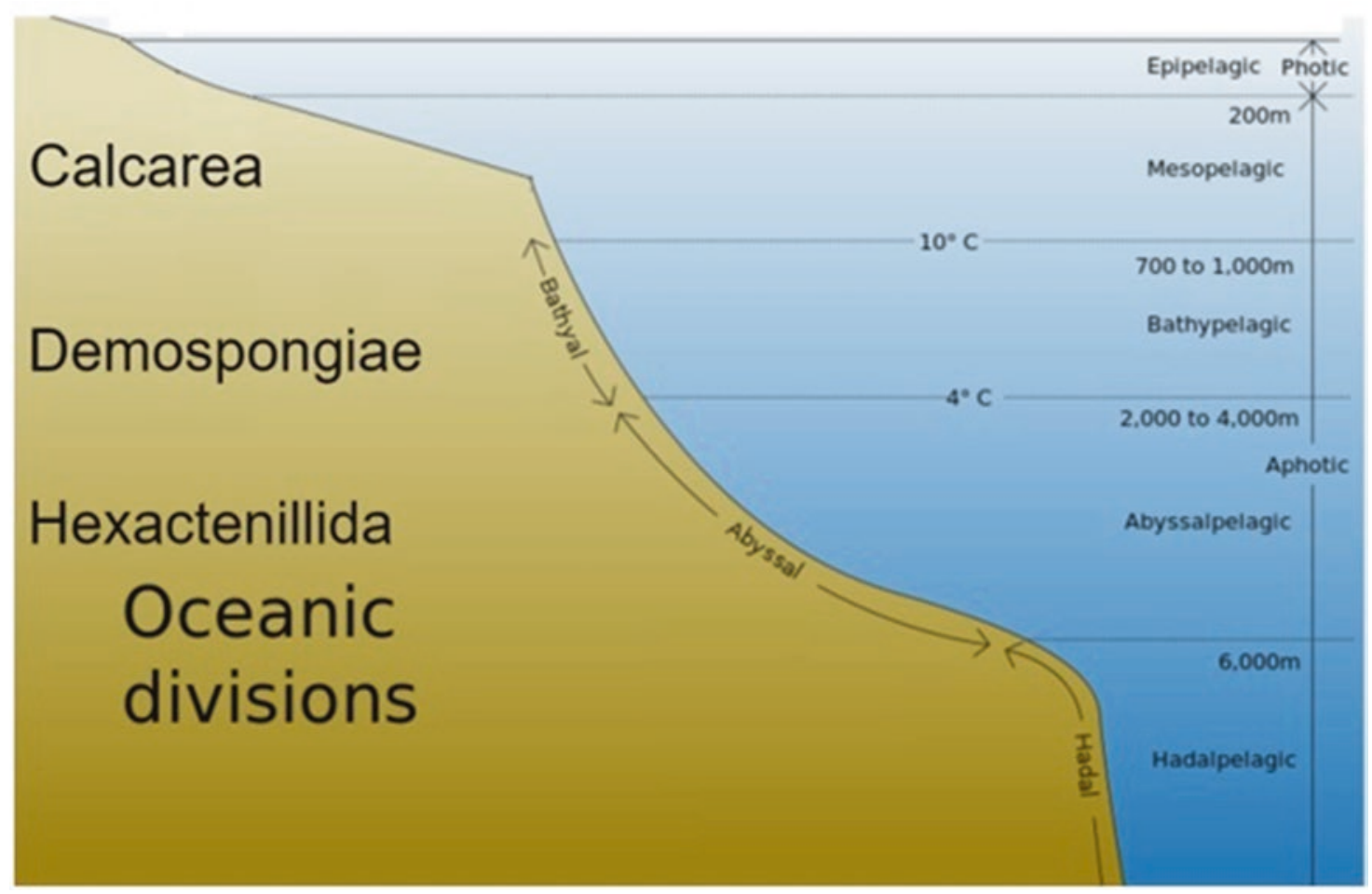

Fig. 9.2 General trend in the bathymetric distribution of three main sponge classes

\subsubsection{Morphology}

Sponges are radially symmetrical sessile filter feeders with a unique aquiferous system, which is an arrangement of afferent and efferent canals conducting water through chambers lined with flagellate choanocyte cells (Simpson 1984). These choanocyte cells propel water actively through the sponge's aquiferous system. Three conditions of this system exist with increasing size and complexity. Demospongiae are known to display the most complex and folded leuconoid condition, with many inhalant canals (ostia) collared by choanocyte cells together with one or more converging exhalant canals (oscula) (Boury-Esnault and Rützler 1997). This folding increases surface area of cells in contact with the surrounding seawater. A large number of the sponge cells (archaeocytes) are totipotent (Müller 2006), meaning they can change form and function. This is especially useful when perturbations occur surrounding a sessile filter feeder. This totipotency allows cells to migrate over the three different cell types present: pinacocytes, mesohyl cells, and choanocytes (Müller 2006). Sponges unlike more complex multicellular organisms do not have nervous, digestive or circulatory systems. In its place, sponges rely on water flowing through their bodies to nourish them with food and oxygen while simultaneously excreting waste. Furthermore, they do not show bilateral symmetry. Instead, sponges show radial symmetry, which allows for maximal efficiency in water flow around the central cavity of the sponge.

\subsubsection{Diet}

Traditionally, researchers thought most sponge species relied on particulate food sources such as bacteria and plankton (Kahn et al. 2015). However, a century ago already, suggestions were made that the traditional view of sponges only feeding upon particulate food sources (Reiswig 1971; Pile et al. 1996, 1997), was insufficient to sustain their nutritional requirements (von Putter 1914).

Nowadays, sponges have been suggested to play an important role in dissolved organic matter (DOM) cycling, thereby fueling "benthic-pelagic coupling" (de Goeij et al. 2013; Lesser 2006). This will be discussed in more details in the section on nutrient cycling (see Sect. 9.4). The question remains, however, if this food source is taken up by the endosymbionts abundantly present in the sponge's tissue or by the sponge itself. The presence of microorganisms in marine sponges has been identified already 80 years ago (Dosse 1939). We know now that sponges may host large amounts of microbes (Gloeckner et al. 2014; Taylor et al. 2007), within some cases up to $40 \%$ of their body mass (Taylor et al. 2007). High microbial abundance (HMA) sponges harbor as many as $10^{8}$ to $10^{10}$ cells $\cdot \mathrm{g}^{-1}$ of sponge wet weight, being two to four orders of magnitude higher than microbial abundance in seawater. Low microbial abundance (LMA) sponges contain $<10^{6}$ cells $\cdot \mathrm{g}^{-1}$ of sponge wet weight. This distinction in microbial abundance could have a considerable effect on their capacity to feed on dissolved compared to particulate 
food sources. Sometimes, 48-80\% of sponge's energy supply comes from these endosymbiotic microbes (Ruppert et al. 2004).

Apart from these food sources, more feeding modes occur in sponges. Some sponges even host photosynthesizing cyanobacteria as endosymbionts to additionally produce food and oxygen (Taylor et al. 2007). For example, sponges often host green algae to provide them with nutrients (Wilkinson 1992). However, some species living in low nutritious environments have become carnivorous sponges (class Demospongiae; family Cladorhizidae) that prey on small crustaceans (Maldonado et al. 2015). Little is known about their ability to capture prey as they count up to a diverse group of 328 species (van Soest et al. 2018) only present in challenging and remote deep-sea environments (Maldonado et al. 2015). Interestingly, these carnivorous sponges have lost most of their aquiferous system and choanocytes. Therefore, it is unsurprising that they are opportunistic feeders together with their endosymbiotic methanotrophic bacteria, which can act as a complementary food source to these deep-sea sponges (Vacelet et al. 1995).

\subsubsection{Life History}

Very little is known about the life cycle of sponges with respect to population dynamics, which is very important for conservation (Maldonado et al. 2015). We do know that, similar to other metazoans, sponges can use sexual reproduction through both viviparous and oviparous species. Even though it is more difficult to study viviparous species, due to internal maturation, we know more about their life cycle compared to oviparous species (Leys and Ereskovsky 2006). Moreover, sightings of egg spawning are rare compared to corals, which suggests a more viviparous lifestyle in sponges, but numbers are still largely unknown. Hexactinellida and Calcarea are viviparous, while most oviparous sponges are found in the Demospongiae (Leys and Ereskovsky 2006).

Similar to corals, sponges are hermaphrodites, in which case they release both sperm and eggs. Due to the absence of organs, gametes are, respectively, transformed from the choanocytes and archeocytes. After the capture of sperm by a host, fertilization and hatching usually occur internally after which the larvae swim out until they find a place to settle. In the case of deepwater Hexactinellida, it is difficult to determine the early life history. Yet some studies have found that two of those species are productive year-round (Ijima and Okada1901; Okada 1928) and one was only seasonally active in early summer (Boury-Esnault and Vacelet 1994). This shows that deepwater environments can be influenced by seasonal fluctuations in some cases.
In contrast, the totipotency of sponge cells also allows for asexual reproduction, by means of four distinct methods: fission, fragmentation, budding, and gemmule formation. Fission creates large clonal populations of especially encrusting sponges, for example Crambe crambe (Calderón et al. 2007). Fragmentation usually occurs in turbulent environments, with, for example, high predation pressure or wave action. Similar to fission, fragmentation allows nearby recolonization within a single habitat in the case of some coral reef species where almost $30 \%$ of a population consists of the same genome (Wulff 1986). Budding occurs in a limited number of species, such as Tethya citrina and Tethya aurantium (Gaino et al. 2006). Finally, one special adaptation is the formation of gemmules predominantly by freshwater species during unfavorable conditions (Kilian 1952). These survival pods form due to considerable temperature differences experienced in freshwater environments in comparison to the ocean (Manconi and Pronzato 2016). These pods of unspecialized cells remain dormant until conditions improve, and they either recolonize their parental skeletons or start a new colony.

Depending on where sponges live, they can grow from a few years in temperate regions to hundreds of years in both tropical and deep-sea environments. Some sponges grow only $0.2 \mathrm{~mm}$ per year which makes specimens of over $1 \mathrm{~m}$ in diameter over 5000 years old (Ruppert et al. 2004).

\subsection{Sponges as Habitat Providers}

Aggregations of sponges are observed in many different environments: coral reefs, mangrove forests, deep sea regions and polar regions. Sponge aggregations have been shown to increase habitat complexity and consequently increase the abundance and biodiversity of benthic associated species (Maldonado et al. 2015). Sponges provide associated species with various services such as shelter from predation, food availability, breeding grounds, and substratum to settle on.

\subsubsection{Tropical Habitat Providers}

On tropical coral reefs, much habitat complexity is provided by corals. However, sponges may also contribute to habitat facilitation either directly or indirectly. For example, on Caribbean reefs, 39 sponge-dwelling fish species were found (Tyler and Böhlke 1972). Different degrees of sponge associations were described by Tyler and Böhlke (1972). Some goby species are classified as obligate sponge-dwellers with some even showing morphologically specialized features for living exclusively inside sponges (Tyler and Böhlke 1972). Other fish species of various families are 
simply fortuitous sponge-dwellers. They only use sponges for the deposit or brooding of eggs and usually live outside of sponges.

Tube- and vase-shaped sponges on coral reefs off Key Largo, Florida, offer a physical barrier that lowers fish predation pressure on brittle stars (Henkel and Pawlik 2005). A chemical defense to deter fish predators is lacking in these sponges, which might make them a preferred surface for deposit feeders next to a predation refuge (Henkel and Pawlik 2005). Sponge-associated brittle stars are known to consume detrital particles adhering to the sponges' surface (Hendler 1984).

Indirectly, sponges in Bahamian caves contribute to increased herbivore abundance on coral reefs. The cave sponges provide corals and algae with enhanced nutrient levels. Coral cover and diversity was higher close to cave openings compared to similar sites further away (Slattery et al. 2013). The increased habitat complexity (through corals) and increased food availability (through algae) result in increased herbivory.

\subsubsection{Deep-Sea Habitat Providers}

In the deep sea, scarcity of complex structural habitat makes sponge grounds one of the most important hotspots for biodiversity (Hogg et al. 2010). Demosponges (Klitgaard 1995; Maldonado et al. 2015) and glass sponges (Beaulieu 2001) have been described as abundant deep-sea habitat providers for associated fauna. Klitgaard (1995) found 242 species associated with deep-sea demosponge aggregations in the North Atlantic. The majority of the sponge-associated fauna used the sponges as substratum.

Biohermal glass sponge reefs increase habitat complexity through biohermal growth. Glass sponges are able to fuse their spicules by a process called secondary silicification. Young sponges settle on the silica skeletons left behind by their ancestors. Fish, crustaceans, nudibranchs, and infaunal polychaetes were found to be more abundant in biohermal glass sponge reefs compared to surrounding areas (Maldonado et al. 2015). This could be due to the improved hydrodynamics of the boundary layer and the shelter the glass sponge reef topography provides to the benthic fauna. Additionally, the energy and nutrient cycling which increases benthic-pelagic coupling (see Sect. 9.4) could also help increase local benthic biodiversity.

Lithistid sponges are known to form rigid massive silica skeletons, which do not easily dissolve. New lithistid sponge recruits can settle on these skeletons, which results in biohermal growth much like glass sponge reef growth. Lithistid sponge mounds on the seabed attract fish and various macroinvertebrates (Maldonado et al. 2015).
In the deep sea off California, USA, 139 taxa of marine organisms were found to be associated with glass sponge stalks (Beaulieu 2001). These micro cryptic habitats were dominated by zoanthids and polychaetes that used the stalks as a hard substratum to grow on.

Carnivorous cladorhizid sponges on the Macquarie Ridge live among many other invertebrates (Maldonado et al. 2015). However, cladorhizid sponges might not increase biodiversity by increasing habitat complexity. Because of their carnivorous characteristics, cladorhizid sponges might prevent larvae from settling.

\subsubsection{Arctic Habitat Providers}

Seabed gouging is a process that is described as drifting ice going through the benthos with the keel when passing through shallower waters. Seabed gouging is known to disturb glass sponge aggregations in the Weddell Sea, Antarctica, leaving behind sponge spicule mats, which serve as a substratum for other organisms (Maldonado et al. 2015). Muddy, soft seabeds were linked to species-poor communities, while solid sponge spicule mats were linked to species-rich communities (Hogg et al. 2010).

\subsubsection{Habitat for Commercially Important Species}

Sponges provide structural habitat which harbors food and/ or provides shelter from predators for fishes and crustaceans (Butler et al. 1995; Ryer et al. 2004; Miller et al. 2012). Some sponge-associated species are also commercially important for fisheries.

High mortality of sponges after cyanobacterial blooms in Florida Bay had consequences for juvenile Caribbean spiny lobster living around these sponges. These lobsters are important to commercial fisheries. The spiny lobsters were exposed to increased predation due to the lack of shelter that was previously provided by sponges (Butler et al. 1995).

Other sponge-associated species are threatened by fishing activities (such as trawling and dredging). When fishing gear (such as nets and long lines) is towed across the seabed, it removes and damages large epibenthic organisms, including sponges. Groundfish (such as cod and ling) are often caught in trawl nets along with sponges (Hogg et al. 2010). Cod, ling, halibut, and Pacific Ocean perch are commercially important fish species that might face negative consequences of sponge habitat loss. Regulation is needed to protect sponge aggregations and the species living in close proximity to them.

Juvenile halibut showed a strong preference for habitats with a $16 \%$ sponge coverage compared to habitats with bare 
sand in laboratory experiments (Ryer et al. 2004). This strong preference could be due to less predation vulnerability for halibuts. Ryer et al. (2004) observed predators being impeded on their prey pursuit by the sponges.

Rockfishes, including the Pacific Ocean perch, are associated with sponges in the southeastern Bering Sea (Miller et al. 2012). The sponges are thought to support diverse and abundant macroinvertebrate communities that serve as prey for rockfish next to providing shelter from predators (Miller et al. 2012).

\subsection{Nutrient Cycling by Sponges}

\subsubsection{Sponge Loop}

Nutrient cycling is essential to maintain a balance between food and waste for all species in an ecosystem food web. In marine environments, primary producers on reefs, such as corals and algae, release $50 \%$ of their mucus, of which $80 \%$ is dissolved directly into the adjacent seawater (Wild et al. 2004, 2008). DOM, consisting of, e.g., carbohydrates, lipids, and proteins, is an abundant potential food source on reefs for microbes (Azam et al. 1983), yet largely unavailable to most heterotrophic reef inhabitants (de Goeij et al. 2013).

Conventionally, microbial degradation of DOM in the water column and sediment has been considered the primary pathway in DOM cycling (Harvey 2006; Wild et al. 2004, 2009). However, decades ago already, suggestions were made that the traditional view of sponges only feeding upon particulate food sources, such as bacteria and plankton (Reiswig 1971; Pile et al. 1996, 1997), was insufficient to sustain their nutritional requirements (von Putter 1914).

Recently, sponges have been discovered to take up DOM, thereby providing an important role in benthic-pelagic coupling (de Goeij et al. 2013; Lesser 2006). Only $42 \%$ of the dissolved carbon taken up from the ambient water is respired by sponges. Therefore, the remainder is most likely either assimilated, used for reproduction, or converted into particulate organic matter (POM) through cell shedding (Alexander et al. 2014; de Goeij et al. 2009). Assimilation, in the form of growth, takes place very little in encrusting sponges; thus, conversion to POM is considered the preferred route. This shedding takes place mainly among the choanocytes which, unsurprisingly, also show high proliferation rates (Alexander et al. 2015) 2900 times faster compared to their normal growth rate of other cells (Ayling 1983). A recent study has revealed that these other cells, specifically from the mesohyl, contribute additionally to the production of POM (Maldonado 2016). This high cell turnover can be a clever mechanism to prevent permanent damage to the sponge caused by environmental stress (de Goeij et al. 2009) and creates the opportu- nity for higher trophic levels to feed on these cells (de Goeij et al. 2013).

The turnover of DOM by sponges is faster than by microbes (van Duyl et al. 2008) and equals the order of magnitude of the gross primary production in the Caribbean reef ecosystem (de Goeij et al. 2013). Thus, apart from the conventional microbial loop (Azam et al. 1983), accounting for only $10 \%$ of nutrient cycling, a sponge loop (de Goeij et al. 2013), accounting for $90 \%$, now supports a major role in the DOM reincorporation pathway. The produced POM is, thereafter, most likely consumed by detritivores, which can be present as associated sponge fauna in so-called consumerresource interactions (de Goeij et al. 2013; Rix et al. 2016).

Most food web models do not include the role sponges have in cycling resources in their environments, which makes the many current models incomplete. Future food web models can be improved by adding sponge energy and nutrient cycling. Moreover, sponges carry out benthic-pelagic coupling, which is crucial to retain nutrients within an environment. Within this section, we will focus on the three important cycles of: carbon, nitrogen and phosphorous, as key components to sustaining life.

\subsubsection{Carbon Cycling by Sponges}

Carbon is one of the main components of biological life forms, and sponges play an important role in carbon cycling in aquatic ecosystems. They take up and release carbon to their environment in several ways (Rix et al. 2017).

Organic matter dissolves in water after extracellular release or cell lysis by primary producers such as phytoplankton, macrophytes, and coral symbionts. Dissolved organic carbon (DOC) concentration can differ in space and time in aquatic ecosystems: 0.7 to $45 \mathrm{mg} \cdot \mathrm{L}^{-1}$ in rivers, 0.7 to $330 \mathrm{mg} \cdot \mathrm{L}^{-1}$ in lakes, and 0.5 to $3.0 \mathrm{mg} \cdot \mathrm{L}^{-1}$ in the ocean (Mulholland 2003). DOC is a large energy resource in aquatic environments and makes up a large part of DOM (Wild et al. 2004). For example, on coral reefs, more than $90 \%$ of the total organic matter consists of DOM (Carlson 2002). However, the carbon fraction of DOM is not readily available to most organisms. Mostly sponges and microbes utilize DOC as an energy source. The DOC uptake of Caribbean coral reef sponges is estimated to be 90 to $350 \mathrm{mmol} \mathrm{C}$. $\mathrm{m}^{-2} \cdot$ day $^{-1}$ (de Goeij and Van Duyl 2007), which is comparable to the gross primary production of 200 to $600 \mathrm{~mm} \mathrm{C}$. $\mathrm{m}^{-2} \cdot$ day $^{-1}$ on coral reefs (Hatcher 1990). DOC removal on coral reefs is mostly accounted for by sponges compared to only 5 to $50 \mathrm{mmol} \mathrm{C} \cdot \mathrm{m}^{-2} \cdot \mathrm{day}^{-1}$ of microbial DOC uptake (de Goeij and Van Duyl 2007; Haas et al. 2011). Total organic carbon (TOC) uptake of coral reef sponges consists predominantly (56 to 97\%) of DOC (de Goeij et al. 2017). Next to filter feeding on carbon sources, some sponge species host 
photoautotrophic symbionts, which photosynthesize and transfer carbon into the sponge's tissue (Wilkinson 1983; Fiore et al. 2013). Wilkinson (1983) found that the carbon fixation rate in coral reef sponges containing symbiotic cyanobacteria was only 2.4 to $6.6 \%$ in dark conditions compared to light conditions. However, sponges usually do not rely chiefly on the symbionts for nutrition. Additionally, apart from dissolved food sources, particulate sources such as bacteria can act as a food source (Kahn et al. 2015).

After DOC uptake, 3.7 to $14.7 \mu \mathrm{mol} \mathrm{DOC} \cdot \mathrm{mmol} \mathrm{C}_{\text {sponge }}{ }^{-1}$. $12 \mathrm{~h}^{-1}$ is assimilated inside sponge cells and spongeassociated microbe cells (Rix et al. 2017). Carbon fixation in sponges is not restricted to the abundance of associated microbes because LMA sponges also take up DOC (de Goeij et al. 2017). Part of the carbon taken up by sponges is respired; another part is used to grow. De Goeij et al. (2017) estimated a daily net biomass increase of $38 \%$ for Halisarca caerulea if all assimilated carbon (61\% of the TOC uptake) would be used for growth. However, sponges do not grow as fast as expected. Only $2.2 \%$ of TOC uptake was used for a daily biomass increase of $1.3 \%$ (Alexander et al. 2015). Instead, sponges show a rapid cell turnover. An average cell cycle of only 6 hours was determined for $H$. caerulea (de Goeij et al. 2009). This cell turnover is the result of rapid cell proliferation and shedding of old cells. Fifteen to $24 \%$ of the carbon assimilated by sponge holobionts is released as particulate organic carbon (POC) (Rix et al. 2017). This is how sponges transform energy in the form of DOC to POC. Carbon becomes available to detritivores (such as ophiuroids, crustaceans, snails, and polychaetes) that consume sponge-derived POC (de Goeij et al. 2013; Rix et al. 2017).

Alternatively, sponges make carbon available to their environment through bio-erosion. Excavating sponges break down calcium carbonate chemically by dissolution and mechanically by chip production (Zundelevich et al. 2007).

\subsubsection{Nitrogen Cycling by Sponges}

Apart from carbon, nitrogen is important in marine ecosystems as it is essential to produce amino acids which in turn make proteins and DNA. Moreover, it is often a limiting nutrient to meet energy requirements in tropical reefs (Muscatine and Porter 1977; Delgado and Lapointe 1994; Fiore et al. 2013). Paradoxically, the abundance of nitrogen in air $(78 \%)$ remains unavailable for animals unless nitrogenfixing bacteria, e.g., cyanobacteria, or to a lesser extent, lightning converts nitrogen to a biologically available form. The (re)cycling of inorganic nitrogen is therefore imperative and occurs via different pathways both in surface waters and the deep sea. Nitrification is considered a source of bioavailable nitrogen, whereas denitrification is considered a sink.
These processes are of importance to species-specific ecosystem services to the surrounding environment. For example, benthic microbial nitrifiers provide nitrate to the root nodular system of macrophytes.

Former studies have shown that inorganic nitrogen cycling in sponges takes place and is mediated by the microbial biofilm present in the sponge's tissue (Taylor et al. 2007; Hoffmann et al. 2005; Fiore et al. 2010; Schläppy et al. 2010; Gloeckner et al. 2014). For example, Mediterranean sponges can actively switch between aerobic and anaerobic metabolism by inhibiting water flow over time (Hoffmann et al. 2008). This could induce anaerobic environments to trigger supposed "coupled nitrification-denitrification," meaning a part of the nitrified nitrate is subsequently transformed into nitrogen gas.

Unsurprisingly, the two most present processes to consider in microbial nitrogen cycling in sponges are nitrification and denitrification (Southwell et al. 2008) (Fig. 9.3). Nitrification is a two-tiered process where ammoniaoxidizing bacteria (AOB) perform the first, often ratelimiting, step from ammonium to nitrite, while the nitrite-oxidizing bacteria (NOB) oxidize the latter to nitrate. AOBs are usually beta- and gamma-proteobacteria, and NOB belong to Nitrobacter and Nitrococcus family (Bayer et al. 2008). Factors that affect nitrification include metabolic interactions in the microbial community and respiration rates but most importantly oxygen concentrations (Müller et al. 2004). If oxygen is lacking, nitrification cannot take place. Sponges, like many other marine invertebrates, usually excrete ammonium as a waste product (Brusca and Brusca 1990). Therefore, the unexpected excretion of nitrate was the first evidence of microbial nitrification within the sponge (Diaz and Ward 1997; Jiménez and Ribes 2007).

Apart from aerobic nitrification, anaerobic processes such as denitrification or anaerobic ammonium oxidation (anammox) also occur regularly in sponges and have, for example, been shown in the tropical sponge Xestospongia muta (Fiore

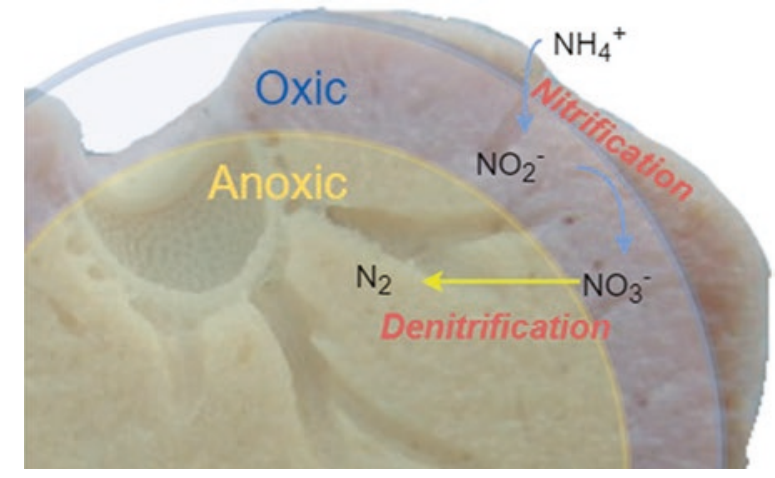

Fig. 9.3 Simplified diagram of nitrification and denitrification superimposed on a vertical slice of a sponge Geodia barretti 
et al. 2013). First, to confirm the presence of anaerobic zones within sponge tissue, Hoffmann et al. (2005) have investigated bacterial metabolic activity ex situ within the HMA sponge Geodia barretti. Their research revealed a steep oxygen profile within intact sponges in which anoxic microenvironments could allow denitrifying bacteria to reduce nitrate in nitrogen gas. Furthermore, Fiore et al. (2013) found a negative efflux of nitrate, indicating that either denitrification or anammox was taking place inside the sponge. However, the Caribbean sponge $X$. muta was actively pumping during the study contradicting the earlier hypothesis of Fiore et al. (2010) where lack of pumping would equal denitrification. Finally, Hoffmann et al. (2009) discovered both nitrification and denitrification in $G$. barretti with rates of 566 and $92 \mathrm{nmol} \mathrm{N} \cdot \mathrm{cm}^{-3}$ sponge $\cdot \mathrm{day}^{-1}$, respectively. However, this research was performed with explants $\left(3 \mathrm{~cm}^{3}\right.$ radial cylinders of cut sponge tissue). Even though sponges are known for their totipotent cells and quick regeneration after damaging (Alexander et al. 2015), using explants alters the aquiferous system to such extent that pumping is most likely inhibited.

Although the deep sea is often viewed as an uninhabitable environment, particular areas like hydrothermal vents, cold seeps, and sponge grounds actually harbor complex ecosystems (Klitgaard 1995; Roberts et al. 2006; Cathalot et al. 2015). Their dependence on nitrogen is influenced by the influx of inorganic and organic nitrogen from surface waters through vertical mixing (Romera-Castillo et al. 2016) and bottom water advection (Davies et al. 2009). Regarding nitrogen cycling, deep-sea sponges (DSS) can be of particular interest, as in some areas they make up $90 \%$ of the benthic biomass (Klitgaard and Tendal 2004; Murillo et al. 2016) and are important filter feeders (Kutti et al. 2013). However, the relevance of DSS is only currently emerging with studies showing that sponges have the potential to recycle essential elements like carbon and nitrogen (Witte et al. 1997; van Oevelen et al. 2009; Rix et al. 2016). As mentioned before in Sect. 4.1, in shallow tropical reefs, sponges are known to retain carbon through the sponge loop, whereas they release nitrogen (de Goeij et al. 2013). Rix et al. (2016) were the first to examine that DSS might have a similar potential in fueling the ecosystem with nitrogen resembling their warm water counterparts. However, she only performed this in ex situ aquarium experiments. Whether a potential cold water sponge loop also takes place in the deep sea is yet to be confirmed, especially regarding the cycling of inorganic nutrients.

\subsubsection{Phosphorous Cycling by Sponges}

Finally, phosphorous is essential for the biological synthesis and for the transfer of energy (Tyrreell 1999). In aquatic environments, phosphorous budgets consist of three compo- nents: particulate phosphorous, dissolved inorganic phosphate, and dissolved organic phosphate (Maldonado et al. 2012). We know that of these three, the latter is present most abundantly (Dyhrman et al. 2007). However, phosphorous cycling has not undergone comprehensive research as the two nutrients aforementioned. Therefore, data is limited to a few studies which have only concluded that both low and high microbial abundant sponges act as a net source of phosphate reviewed in Maldonado et al. (2012). Further research into phosphorous cycling by sponges would give us more insight into the potential limiting factors of sponge habitats.

\subsection{Marine Natural Products from Sponges}

\subsubsection{Introduction}

Since the early Egyptian times, sponge skeletons have been harvested for its cleaning properties and as hygienic tools (Pronzato 2003). Likewise, the earliest medicinal feature, in Greek times, a cold wet sponge placed on the heart, would resurrect the fainted (Jesionowski et al. 2018). However, these days, the capacities of sponges have shifted from a biomaterial to a biomolecular source (Jesionowski et al. 2018). Within the last 20 years, the detection of marine natural products (MNP) has increased, with an estimate of 15,000 MNPs discovered until 2010 (Hu et al. 2011). In the search for bioactive compounds in the marine environment, vertebrate animals such as fish, sharks, and snakes have been examined. Among the invertebrates, more groups have been examined including tunicates, echinoderms, algae, mollusks, corals, and sponges. Finally, microorganisms were examined, and of those several bacteria, fungi, and cyanobacteria showed potential (Alonso et al. 2003). The fact that sponges can harbor high densities of microorganisms in the mesohyl layer makes them very potent study objects for novel bioactive compounds (Alexander 2015). Moreover, sponges lack an immune system, protective armor, and mobility which pressed on the evolution to synthesize compounds for defensive purposes. For example, instead of an immune system, when invaded with foreign material, sponges produce a range of chemicals, such as 3-alkyl-pyridinium, that inhibits movement of surrounding cells preventing the use of the sponge's internal transport system (Sepčić et al. 1999).

Interestingly, there is considerable debate about whether sponges are the true producer of these compounds and not just hosts to the true producers: microorganisms (Jensen and Fenical 1994; Bultel-Poncé et al. 1997; Hentschel et al. 2006 reviewed in Mehbub et al. 2016b). It would not be a surprise if the majority of these compounds are a result of the symbiotic microorganisms rather than the host, considering in HMA sponges the body mass could be accounted for by bac- 
teria to up to $40 \%$ (Taylor et al. 2007). Either way, it is important to investigate the possibilities for MNPs within the holobiont as they ultimately provide the compound as a whole organism. This holobiont approach does lead to some discussion about the true producer and if they can do so without each other's presence. Several reviews have discussed this. In Jensen and Fenical (1994), the problem is mentioned that the sponge does contain a microbial community distinct of the surrounding water, implying that bacteria need the sponge host to be initially present. A prime example of misjudgments of the true producer was found after flow cytometric separation of sponge and microbial fraction localizing the true producer: a prokaryotic cell (Unson and Faulkner 1993).

\subsubsection{Potential for Exploitation}

The potential to exploit marine sources for pharmaceuticals has been of major importance in recent times since we cannot only rely on terrestrial sources alone. Moreover, it is of importance to investigate these potential pharmaceuticals, because infectious microorganisms constantly evolve a resistance against current pharmaceuticals. Several reviews have focused on MNPs in general (Faulkner 2000; Blunt et al. 2017, 2018); yet some have also focused only on spongespecific MNPs (Mehbub et al. 2016a).

The reason for sponges to entail such a vast majority of the MNPs found in the marine environment could well be caused by their survival over the past 580 million years. During this time, they have undergone huge environmental changes which induced specialization and formation of vastly different species over the entire aquatic environment. Sponges are at present divided into 4 distinct classes, 25 orders, 128 families, and 680 genera (Abad et al. 2011). These specializations over all the different groups together with their capacity to hold endosymbionts led to the production of a large range of (secondary) metabolites.

Among all marine species, sponges are the most investigated with nearly $30 \%$ of all MNPs discovered (Mehbub et al. 2016a). This accounts for a total of 4851 compounds of which 1499 isolated only between 2008 and 2012. The compounds were classified into 18 chemical classes among them: acids, alkaloids, esters, fatty acids, and further less relevant groups (Mehbub et al. 2016a). These compounds contain a wide variety of bioactivities: anticancer, antiviral, antibacterial, anti-inflammatory, and many more neural activities (Chakraborty et al. 2009). The latter is of importance because of the vast presence of patients with neurodegenerative diseases especially in high-income countries (Global Health Estimates 2016). Moreover, many studies have investigated the neuroprotective capacities of the MNPs in sponges. Compounds were found with activities such as modulation of the neurotransmitters acetylcholinesterase and glutamate, decreasing oxidative stress, enrichment of serotonin, and neurite growth (Alghazwi et al. 2016). However, none of these compounds have yet been developed as a finalized marine pharmaceutical.

\subsubsection{Culturing of Sponges}

Since the eighteenth century, reconstructive growth of sponges has been recorded, with major advances made at the beginning of the twentieth century by Henry Moore in Florida (Jesionowski et al. 2018). Later research has investigated the potential of secondary metabolites regarding their antimicrobial activity (Thompson et al. 1985) acting as therapeutic drugs, collagen, and optical equipment (Munro et al. 1999). However, this has so far been held back by what is referred to as "the supply problem" (Osinga et al. 2003). The supply problem states that we are limited by the small amount of chemical present within the sponge compared to its biomass. Moreover, the dilution effect of the ocean requires compounds to be very stable and highly active (Abad et al. 2011) which would explain the low quantities found. To overcome this, we are required to grow enormous sponge biomass to perform acceptable preclinical and clinical trials. As harvesting the enormous sponge biomass from the environment would not be sustainable, therefore we have to look at alternatives. Thus, opportunities in biotechnological methods are progressively favored to avoid the supply problem. One possible solution is to have the spongeassociated microorganisms to flourish independently of their host to produce larger quantities of MNPs. Another growing area is the use of sponge cell cultures, which avoids the complex environment necessary for whole organisms (Müller et al. 2000). Yet some advance has been made to express these biosynthetic pathways of interest in more easily cultivatable hosts to overcome the supply problem (Wilson et al. 2014). Nevertheless, large-scale production of sponge biomass for MNPs remains unsuccessful.

As mentioned afore, sponges can grow in vastly different natural environments, from the deep sea to tropical reefs. At present, in situ culture has been the only successful approach at harvesting considerable biomass of sponges. The usual method is to use asexual reproduction by fragmentation which creates explants hanging from buoy lines in the water column (Osinga et al. 2003). However, in situ culturing has serious drawbacks such as incoming diseases, abrupt weather changes, or habitat disruption. This has impeded large-scale in situ production. Therefore, Osinga et al. (2003) started to experiment with growing sponges in vivo in bioreactors. They succeeded to grow a tropical sponge Pseudosuberites andrewsi on a single marine diatom species either intact or as a filtered crude extract. However, unlike freshwater sponges 
Ephydatia fluviatilis and Spongilla alba, which have shown to grow successfully on a stock of Escherichia coli (Francis et al. 1990), the lack in further culture literature might explain that proper food source or mixture to grow marine sponges is still elusive. Though discussion remains even on the selection of one food source, we know marine sponges feed on several food sources simultaneously, such as: picoplankton, bacteria, viruses and dissolved organic substrates (de Goeij et al. 2013). It could well be that the quality of the particulate food sources and the composition of these dissolved organic substrates are decisive. Yet apart from food sources, there are abiotic variables (such as temperature, salinity, and light) that can determine growth. Therefore, more research should be undertaken finding the balance in food sources while breeding marine sponges under various laboratory conditions.

\subsection{Conclusions}

In this review, we have tried to outline the importance of sponges to their environments as well as to humans. Sponges are a diverse phylum (consisting of more than 8000 species). In this phylum, a broad range of morphologies, feeding habits, and reproduction strategies are present. Much about these various characteristics of sponges is yet to be discovered and understood. These future discoveries are not only interesting for sponge-specific knowledge but also of importance to a wider understanding of evolution and aquatic ecosystems in general.

Sponges are important to their environment for multiple reasons. Sponges provide habitat and food for fish, crustaceans, and many other animals in a variety of ecosystems ranging from tropical coral reefs to deep-sea sponge grounds. Among these sponge-dwelling organisms are even commercially important species.

Additionally, sponges shape the communities surrounding them by playing a significant role in the cycling of energy and nutrients. Sponges make carbon, nitrogen, and potentially phosphorus available to higher trophic levels. By doing so, these elements are retained within the ecosystems sponges live in and would otherwise not be available to many organisms.

Lastly, sponges are also important to humans in upcoming pharmaceutical research. The high abundance of symbiotic microorganisms living within sponges makes sponges good candidates for novel bioactive compound discovery. It is expected that sponge-associated marine natural products have potential as bioactive compounds in drugs. Therefore, it is important to invest time in uncovering the importance of this phylum within all aquatic ecosystems.

\section{Appendix}

This article is related to the YOUMARES 9 conference session no. 11: "Sponges (Porifera): Fantastic filter feeders." The original Call for Abstracts and the abstracts of the presentations within this session can be found in the Appendix "Conference Sessions and Abstracts", Chapter "9 Sponges (Porifera): Fantastic filter feeders", of this book.

\section{References}

Abad M, Bedoya L, Bermejo P (2011) Marine compounds and their antimicrobial activities. In: Méndez-Vilas A (ed) Science against microbial pathogens: communicating current research and technological advances, vol 2, 3rd edn. Formatex, Badajoz, pp 1293-1306

Adamska M (2016) Sponges as models to study emergence of complex animals. Curr Opin Genet Dev 39:21-28. https://doi.org/10.1016/j. gde.2016.05.026

Alexander B (2015) Cell turnover in marine sponges: insight into poriferan physiology and nutrient cycling in benthic ecosystems. Dissertation, University of Amsterdam

Alexander B, Liebrand K, Osinga R et al (2014) Cell turnover and detritus production in marine sponges from tropical and temperate benthic ecosystems. PLoS One 9(10):e109486. https://doi.org/10.1371/ journal.pone.0109486

Alexander B, Achlatis M, Osinga R et al (2015) Cell kinetics during regeneration in the sponge Halisarca caerulea: how local is the response to tissue damage? PeerJ 3:e820. https://doi.org/10.7717/ peerj. 820

Alghazwi M, Qi Kan Y, Zhang W et al (2016) Neuroprotective activities of marine natural products from marine sponges. Curr Med Chem 23(4):360-382

Alonso D, Khalil Z, Satkunanthan N et al (2003) Drugs from the sea: conotoxins as drug leads for neuropathic pain and other neurological conditions. Mini-Rev Med Chem 3(7):785-787

Ayling AL (1983) Growth and regeneration rates in thinly encrusting demospongiae from temperate waters. Biol Bull 165(2):343-352. https://doi.org/10.2307/1541200

Azam F, Fenchel T, Field J et al (1983) The ecological role of watercolumn microbes in the sea. Mar Ecol Prog Ser 10:257-263. https:// doi.org/10.3354/meps010257

Barnes RD (1982) Invertebrate zoology. Saunders College Publishing, Philadelphia

Bayer K, Schmitt S, Hentschel U (2008) Physiology, phylogeny and in situ evidence for bacterial and archaeal nitrifiers in the marine sponge Aplysina aerophoba. Environ Microbiol 10(11):2942-2955

Beaulieu SE (2001) Life on glass houses: sponge stalk communities in the deep sea. Mar Biol 138(4):803-817

Bell JJ, Barnes DKA (2000) The influences of bathymetry and flow regime upon the morphology of sublittoral sponge communities. J Mar Biol Assoc UK 80:707-718

Blunt WJ, Copp RB, Keyzers AR et al (2017) Marine natural products. Nat Prod Rep 34:235-294. https://doi.org/10.1039/C6NP00124F

Blunt WJ, Carroll RA, Copp RB et al (2018) Marine natural products. Nat Prod Rep 35:8-53. https://doi.org/10.1039/C7NP00052A

Boury-Esnault N, Rützler K (1997) Thesaurus of sponge morphology. Smithson Contrib Zool 596:1-55. https://doi.org/10.5479/ si.00810282.596

Boury-Esnault N, Vacelet J (1994) Preliminary studies on the organization and development of a hexactinellid sponge from a Mediterranean 
cave, Oopsacas minuta. In: vanSoestRWM, vanKempenTMG, BraekmanJet al (eds) Sponges in time and space: biology, chemistry, paleontology. 4th international Porifera Congress, Amsterdam, April1993. Balkema, Rotterdam, pp407-416

Brusca R, Brusca G (1990) Phylum Porifera: the sponges. In: Brusca R, Brusca G (eds) The invertebrates, 2nd edn. Sinaeur Press, Sunderland, pp 181-210

Bultel-Poncé V, Debitus C, Blond A et al (1997) Lutoside: an acyl1-(acyl-6'-mannobiosyl)-3-glycerol isolated from the spongeassociated bacterium Micrococcus luteus. Tetrahedron Lett 38:5805-5808. https://doi.org/10.1016/S0040-4039(97)01283-5

Butler MJ, Hunt JH, Herrnkind WF et al (1995) Cascading disturbances in Florida bay, USA: cyanobacteria blooms, sponge mortality, and implications for juvenile spiny lobsters Panulirus argus. Mar Ecol Prog Ser 129:119-125

Calderón I, Ortega N, Duran S et al (2007) Finding the relevant scale: clonality and genetic structure in a marine invertebrate (Crambe crambe, Porifera). Mol Ecol 16:1799-1810. https://doi. org/10.1111/j.1365-294X.2007.03276

Carlson CA (2002) Production and removal processes. In: Hansell DA, Carlson CA (eds) Biogeochemistry of marine dissolved organic matter, 2nd edn. Academic Press, London, pp 91-151

Cathalot C, Van Oevelen D, Cox TJS et al (2015) Cold-water coral reefs and adjacent sponge grounds: hotspots of benthic respiration and organic carbon cycling in the deep sea. Front Mar Sci 2:37. https:// doi.org/10.3389/fmars.2015.00037

Chakraborty C, Hsu CH, Wen ZH et al (2009) Anticancer drugs discovery and development from marine organisms. Curr Top Med Chem 9(16):1536-1545

Davies AJ, Duineveld GCA, Lavaleye MSS et al (2009) Downwelling and deep-water bottom currents as food supply mechanisms to the cold-water coral Lophelia pertusa (Scleractinia) at the Mingulay reef complex. Limnol Oceanogr 54(2):620-629. https://doi. org/10.4319/lo.2009.54.2.0620

de Goeij JM, van Duyl FC (2007) Coral cavities are sinks of dissolved organic carbon (DOC). Limnol Oceanogr 52(6):2608-2617

de Goeij JM, de Kluijver A, van Duyl FC et al (2009) Cell kinetics of the marine sponge Halisarca caerulea reveal rapid cell turnover and shedding. J Exp Biol 212(23):3892-3900

de Goeij JM, van Oevelen D, Vermeij MJA et al (2013) Surviving in a Marine Desert: the sponge loop retains resources within coral reefs. Science 342(6154): 108-110

de Goeij JM, Lesser MP, Pawlik JR (2017) Nutrient fluxes and ecological functions of coral reef sponges in a changing ocean. In: Carballo JL, Bell JJ (eds) Climate change, ocean acidification and sponges, 1st edn. Springer, Cham, pp 373-410

Delgado O, Lapointe BE (1994) Nutrient-limited productivity of calcareous versus fleshy macroalgae in a eutrophic, carbonate-rich tropical marine environment. Coral Reefs 13(3):151-159. https:// doi.org/10.1007/BF00301191

Diaz MC, Rützler K (2001) Sponges: an essential component of Caribbean coral reefs. Bull Mar Sci 69(2):535-546

Diaz MC, Ward BB (1997) Sponge-mediated nitrification in tropical benthic communities. Mar Ecol Prog Ser 156:97-107

Dosse G (1939) Bakterien-und Pilzbefunde sowie pathologische und Fäulnisvorgänge in Meeres-und Süßwasserschwämmen. Z Parasitenkd 11(2-3):331-356

Dunn CW, Hejnol A, Matus DQ et al (2008) Broad phylogenomic sampling improves resolution of the animal tree of life. Nature 452:745-749. https://doi.org/10.1038/nature06614

Dyhrman ST, Ammerman JW, van Mooy BAS (2007) Microbes and the marine phosphorus cycle. Oceanography 20:110-116

Faulkner DJ (2000) Marine natural products. Nat Prod Rep 17:7-55. https://doi.org/10.1039/A809395D
Fiore CL, Jarett JK, Olson ND et al (2010) Nitrogen fixation and nitrogen transformations in marine symbioses. Trends Microbiol 18(10):455-463. https://doi.org/10.1016/j.tim.2010.07.001

Fiore CL, Baker DM, Lesser MP (2013) Nitrogen biogeochemistry in the Caribbean sponge, Xestospongia muta: a source or sink of dissolved inorganic nitrogen? PLoS One 8(8):e72961. https://doi. org/10.1371/journal.pone.0072961

Francis JC, Bart L, Poirrier MA (1990) Effect of medium pH on the growth rate of Ephydatia fluviatilis in laboratory culture. In: RützlerK, MacintyreVV, SmithKT (eds) New perspectives in sponge biology. 3rd international sponge conference, Woods Hole, November 1985. Smithsonian Institution Press, Washington, DC, pp 485-490

Gaino E, Scalera Liaci L, Sciscioli M et al (2006) Investigation of the budding process in Tethya citrina and Tethya aurantium (Porifera, Demospongiae). Zoomorphology 125:87. https://doi.org/10.1007/ s00435-006-0015-z

Gazave E, Lapébie P, Ereskovsky AV et al (2012) No longer Demospongiae: Homoscleromorpha formal nomination as a fourth class of Porifera. In: Maldonado M, Turon X, Becerro M et al (eds) Ancient animals, New challenges, Developments in hydrobiology, vol 219. Springer, Dordrecht, pp 3-10

Gili JM, Coma R (1998) Benthic suspension feeders: their paramount role in littoral marine food webs. Trends Ecol Evol 13:316-321. https://doi.org/10.1016/S0169-5347(98)01365-2

Global Health Estimates (2016) Deaths by Cause, Age, Sex, by Country and by Region, 2000-2016. World Health Organization, Geneva. http://www.who.int/healthinfo/global_burden_disease/estimates/ en/. Accessed 31 Oct 2018

Gloeckner V, Wehrl M, Moitinho-Silva L et al (2014) The HMALMA dichotomy revisited: an electron microscopical survey of 56 sponge species. Biol Bull 227(1):78-88. https://doi.org/10.1086/ BBLv227n1p78

Griffiths JR, Kadin M, Nascimento FJ et al (2017) The importance of benthic-pelagic coupling for marine ecosystem functioning in a changing world. Glob Chang Biol 23(6):2179-2196

Haas AF, Nelson CE, Wegley Kelly Let al (2011) Effects of coral reef benthic primary producers on dissolved organic carbon and microbial activity. PLOS ONE 6:e27973. doi:https://doi.org/10.1371/ journal.pone.0027973 pmid:22125645

Harvey HR (2006) Sources and cycling of organic matter in the marine water column. In: Volkman JK (ed) Marine organic matter: biomarkers, isotopes and DNA, The handbook of environmental chemistry, vol 2N. Springer, Heidelberg, pp 1-25

Hatcher BG (1990) Coral reef primary productivity. A hierarchy of pattern and process. Trends Ecol Evol 5(5):149-155. doi:https://doi. org/10.1016/0169-5347(90)90221-X pmid:21232343

Hendler G (1984) The association of Ophiothrix lineata and Callyspongia vaginalis: a Brittlestar-sponge cleaning symbiosis? Mar Ecol 5(1):9-27

Henkel TP, Pawlik JR (2005) Habitat use by sponge-dwelling brittle stars. Mar Biol 146(2):301-313

Hentschel U, Usher KM, Taylor MW (2006) Marine sponges as microbial fermenters. FEMS Microbiol Ecol 55(2):167-177. https://doi. org/10.1111/j.1574-6941.2005.00046.x

Hoffmann F, Larsen O, Thiel V et al (2005) An anaerobic world in sponges. Geomicrobiol J 22(1-2):1-10. https://doi. org/10.1080/01490450590922505

Hoffmann F, Røy H, Bayer K et al (2008) Oxygen dynamics and transport in the Mediterranean sponge Aplysina aerophoba. Mar Biol 153(6):1257-1264. https://doi.org/10.1007/s00227-008-0905-3

Hoffmann F, Radax R, Woebken D et al (2009) Complex nitrogen cycling in the sponge Geodia barretti. Environ Microbiol 11(9):2228-2243. https://doi.org/10.1111/j.1462-2920.2009.01944.x 
Hogg MM, Tendal OS, Conway KWet al (2010) Deep-sea sponge grounds: reservoirs of biodiversity. UNEP-WCMC biodiversity series, vol 32. UNEP-WCMC, Cambridge

Hooper JNA, van Soest RWM (2002) Systema Porifera: a guide to the classification of sponges. Kluwer Academic/Plenum Publishers, New York

Hu GP, Yuan J, Sun L et al (2011) Statistical research on marine natural products based on data obtained between 1985 and 2008. Mar Drugs 9(4):514-525

Ijima I, Okada Y (1901) Studies on the Hexactinellida: contribution I. (Euplectellidae). Imperial University of Tokyo, Tokyo. https://doi. org/10.5962/bhl.title.16267

Jensen PR, Fenical W (1994) Strategies for the discovery of secondary metabolites from marine bacteria: ecological perspectives. Annu Rev Microbiol 48:559-584

Jesionowski T, Norman M, Żółtowska-Aksamitowska S et al (2018) Marine spongin: naturally prefabricated 3D scaffold-based biomaterial. Mar Drugs 16(3):88

Jiménez E, Ribes M (2007) Sponges as a source of dissolved inorganic nitrogen: nitrification mediated by temperate sponges. Limnol Oceanogr 52(3):948-958. https://doi.org/10.4319/ 10.2007.52.3.0948

Kahn AS, Yahel G, Chu JW et al (2015) Benthic grazing and carbon sequestration by deep-water glass sponge reefs. Limnol Oceanogr 60(1):78-88

Kilian EF (1952) Wasserströmung und Nahrungsaufnahme beim Süsswasserschwamm Ephydatia fluviatilis. Z Vgl Physiol 34:407-447

Klitgaard AB (1995) The fauna associated with outer shelf and upper slope sponges (Porifera, Demospongiae) at the Faroe Islands, northeastern Atlantic. Sarsia 80(1):1-22

Klitgaard AB, Tendal OS (2004) Distribution and species composition of mass occurrences of large-sized sponges in the Northeast Atlantic. Prog Oceanogr 61(1):57-98. https://doi.org/10.1016/j. pocean.2004.06.002

Kutti T, Bannister RJ, Fosså JH (2013) Community structure and ecological function of deep-water sponge grounds in the Traenadypet MPA - Northern Norwegian continental shelf. Cont Shelf Res 69:21-30. https://doi.org/10.1016/j.csr.2013.09.011

Lesser MP (2006) Benthic-pelagic coupling on coral reefs: feeding and growth of Caribbean sponges. J Exp Mar Biol Ecol 328(2):277-288

Leys SP, Ereskovsky AV (2006) Embryogenesis and larval differentiation in sponges. Canadian J Zool 84(2):262-287

Maldonado M (2016) Sponge waste that fuels marine oligotrophic food webs: a re-assessment of its origin and nature. Mar Ecol 37(3):477_ 491. https://doi.org/10.1111/maec.12256

Maldonado M, Young CM (1996) Bathymetric patterns of sponge distribution on the Bahamian slope. Deep-Sea Res I 43:897-915. https://doi.org/10.1016/0967-0637(96)00042-8

Maldonado M, Ribes M, van Duyl FC (2012) Nutrient fluxes through sponges: biology, budgets, and ecological implications. Adv Mar Biol 62:113-182

Maldonado M, Aguilar R, Bannister RJ et al (2015) Sponge grounds as key marine habitats: a synthetic review of types, structure, functional roles, and conservation concerns. In: Rossi S, Bramanti L, Gori A et al (eds) Marine animal forests: the ecology of benthic biodiversity hotspots, 1 st edn. Springer, Switzerland, pp 1-39

Manconi R, Pronzato R (2016) How to survive and persist in temporary freshwater? Adaptive traits of sponges (Porifera: Spongillida): a review. Hydrobiologia 782:11-22. https://doi.org/10.1007/ s10750-016-2714-x

McMurray SE, Pawlik JR, Finelli CM (2017) Demography alters carbon flux for a dominant benthic suspension feeder, the giant barrel sponge, on Conch reef, Florida keys. Funct Ecol 31(11):2188-2198. https://doi.org/10.1111/1365-2435.12908
Mehbub MF, Perkins MV, Zhang W et al (2016a) New marine natural products from sponges (Porifera) of the order Dictyoceratida (2001 to 2012); a promising source for drug discovery, exploration and future prospects. Biotechnol Adv 34:473-491. https://doi. org/10.1016/j.biotechadv.2015.12.008

Mehbub MF, Tanner JE, Barnett SJ et al (2016b) The role of spongebacteria interactions: the sponge Aplysilla rosea challenged by its associated bacterium Streptomyces ACT-52A in a controlled aquarium system. Appl Microbiol Biotechnol 100:10609-10626. https:// doi.org/10.1007/s00253-016-7878-9

Miller RJ, Hocevar J, Stone RP et al (2012) Structure-forming corals and sponges and their use as fish habitat in Bering Sea submarine canyons. PLoS One 7(3):e33885. https://doi.org/10.1371/journal. pone. 0033885

Mulholland PJ (2003) Large-scale patterns in dissolved organic carbon concentration, flux, and sources. In: Findlay SEG, Sinsabaugh RL (eds) Aquatic ecosystems, 2nd edn. Academic, London, pp 139-159

Müller WEG (2006) The stem cell concept in sponges (Porifera): metazoan traits. Semin Cell Dev Biol 17:481-491. https://doi. org/10.1016/j.semcdb.2006.05.006

Müller WEG, Böhm M, Batel R et al (2000) Application of cell culture for the production of bioactive compounds from sponges: synthesis of Avarol by primmorphs from Dysidea avara. J Nat Prod 63:1077-1081

Müller WEG, Grebenjuk VA, Thakur NL et al (2004) Oxygen-controlled bacterial growth in the sponge Suberites domuncula: toward a molecular understanding of the symbiotic relationships between sponge and bacteria. Appl Environ Microbiol 70(4):2332-2341

Munro MHG, Blunt JW, Dumdei EJ et al (1999) The discovery and development of marine compounds with pharmaceutical potential. J Biotechnol 70(1-3):15-25. https://doi.org/10.1016/ S0168-1656(99)00052-8

Murillo FJ, Kenchington E, Lawson JM et al (2016) Ancient deepsea sponge grounds on the Flemish Cap and Grand Bank, Northwest Atlantic. Mar Biol 163(3):63. https://doi.org/10.1007/ s00227-016-2839-5

Muscatine L, Porter JW (1977) Reef corals: mutualistic symbioses adapted to nutrient-poor environments. Bioscience 27(7):454-460. https://doi.org/10.2307/1297526

Nakanishi N, Sogabe S, Degnan BM (2014) Evolutionary origin of gastrulation: insights from sponge development. BMC Biol 12:26. https://doi.org/10.1186/1741-7007-12-26

Okada Y (1928) On the development of a hexactinellid sponge, Farrea sollasii. J Fac Sci Imper Univ Tok Sect IV Zool 2:1-27

Osinga R, Belarbi EH, Grima EM et al (2003) Progress towards a controlled culture of the marine sponge Pseudosuberitesandrewsi in a bioreactor. J Biotechnol 100(2):141-146

Pile AJ, Patterson M, Witman J et al (1996) In situ grazing on plankton $<10 \mu \mathrm{m}$ by the boreal sponge Mycale lingua. Mar Ecol Prog Ser 141:95-102. https://doi.org/10.3354/meps141095

Pile AJ, Patterson MR, Savarese M et al (1997) Trophic effects of sponge feeding within Lake Baikal's littoral zone. 2. Sponge abundance, diet, feeding efficiency, and carbon flux. Limnol Oceanogr 42(1):178-184. https://doi.org/10.4319/lo.1997.42.1.0178

Pisani D, Pett W, Dohrmann M et al (2015) Genomic data do not support comb jellies as the sister group to all other animals. Proc Natl Acad Sci U S A 112(50):15402-15407. https://doi.org/10.1073/ pnas. 1518127112

Pronzato R (2003) Mediterranean Sponge fauna: a biological, historical and cultural heritage. Biogeographia 24:91-99. https://doi. org/10.21426/B6110118

Reid REH (1968) Bathymetric distributions of Calcarea and Hexactinellida in the present and the past. Geol Mag 105:546-559. https://doi.org/10.1017/S0016756800055904 
Reiswig HM (1971) Particle feeding in natural populations of three marine demosponges. Biol Bull 141:568-591. https://doi. org/10.2307/1540270

Rix L, de Goeij JM, Mueller CE et al (2016) Coral mucus fuels the sponge loop in warm- and cold-water coral reef ecosystems. Sci Rep 6(1):18715. https://doi.org/10.1038/srep18715

Rix L, Goeij JM, van Oevelen D et al (2017) Differential recycling of coral and algal dissolved organic matter via the sponge loop. Funct Ecol 31(3):778-789

Roberts JM, Wheeler AJ, Freiwald A (2006) Reefs of the deep: the biology and geology of cold-water coral ecosystems. Science 312(5773):543-547

Romera-Castillo C, Letscher RT, Hansell DA (2016) New nutrients exert fundamental control on dissolved organic carbon accumulation in the surface Atlantic Ocean. Proc Natl Acad Sci U S A 113(38):10497-10502. https://doi.org/10.1073/pnas.1605344113

Ruppert EE, Fox RS, Barnes RD (2004) Invertebrate zoology, 7th edn. Cengage Learning US, Fort Worth

Ryer CH, Stoner AW, Titgen RH (2004) Behavioral mechanisms underlying the refuge value of benthic habitat structure for two flatfishes with differing anti-predator strategies. Mar Ecol Prog Ser 268:231-243

Schläppy ML, Schöttner SI, Lavik G et al (2010) Evidence of nitrification and denitrification in high and low microbial abundance sponges. Mar Biol 157(3):593-602. https://doi.org/10.1007/ s00227-009-1344-5

Sepčić K, Poklar N, Vesnaver G et al (1999) Interaction of 3-Alkylpyridinium polymers from the sea sponge Renierasarai with insect acetylcholinesterase. J Protein Chem 18:251-257. https://doi org/10.1023/A:1021096726288

Simion P, Philippe H, Baurain D et al (2017) A large and consistent Phylogenomic dataset supports sponges as the sister group to all other animals. Curr Biol 27:958-967. https://doi.org/10.1016/j. cub.2017.02.031

Simpson TL (1984) The cell biology of sponges. Springer, New York

Slattery M, Gochfeld DJ, Easson CG et al (2013) Facilitation of coral reef biodiversity and health by cave sponge communities. Mar Ecol Prog Ser 476:71-86

Southwell MW, Popp BN, Martens CS (2008) Nitrification controls on fluxes and isotopic composition of nitrate from Florida keys sponges. Mar Chem 108(1):96-108. https://doi.org/10.1016/j. marchem.2007.10.005

Taylor MW, Radax R, Steger D et al (2007) Sponge-associated microorganisms: evolution, ecology, and biotechnological potential. Microbiol Mol Biol Rev 71(2):295-347. https://doi.org/10.1128/ MMBR.00040-06

Thompson JE, Walker RP, Faulkner DJ (1985) Screening and bioassays for biologically-active substances from forty marine sponge species from San Diego, California, USA. Mar Biol 88(1):11-21. https:// doi.org/10.1007/BF00393038

Tyler JC, Böhlke JE (1972) Records of sponge-dwelling fishes, primarily of the Caribbean. Bull Mar Sci 22(3):601-642

Tyrreell T (1999) The relative influences of nitrogen and phosphorus on oceanic primary production. Nature 400:525-531
Unson MD, Faulkner DJ (1993) Cyanobacterial symbiont biosynthesis of chlorinated metabolites from Dysideaherbacea (Porifera). Experientia 49:349-353. https://doi.org/10.1007/BF01923420

Vacelet J (1988) Indications de profondeur données par les Spongiaires dans les milieux benthiques actuels. Géol Médit 15:13-26. https:// doi.org/10.3406/geolm.1988.1392

Vacelet J, Boury-Esnault N, Fiala-Medioni A et al (1995) A methanotrophic carnivorous sponge. Nature 377:296. https://doi. org/10.1038/377296a0

van Duyl F, Hegeman J, Hoogstraten A et al (2008) Dissolved carbon fixation by sponge-microbe consortia of deep water coral mounds in the northeastern Atlantic Ocean. Mar Ecol Prog Ser 358:137150. https://doi.org/10.3354/meps07370

van Oevelen D, Duineveld G, Lavaleye Met al (2009) The cold-water coral community as a hot spot for carbon cycling on continental margins: a food-web analysis from Rockall Bank (Northeast Atlantic). Limnol Oceanogr54(6):1829-1844

van Soest RWM, Boury-Esnault N, HooperJNAet al (2018) World Porifera database. http://www.marinespecies.org/porifera. Accessed 30 Oct 2018

Von Putter A (1914) Der Stoffwechsel der Kieselschwämme. Z Allg Physiol 16:65-114

Wild C, Huettel M, Klueter A et al (2004) Coral mucus functions as an energy carrier and particle trap in the reef ecosystem. Nature 428(6978):66-70. https://doi.org/10.1038/nature02344

Wild C, Mayr C, Wehrmann L et al (2008) Organic matter release by cold water corals and its implication for fauna-microbe interaction. Mar Ecol Prog Ser 372:67-75

Wild C, Wehrmann L, Mayr C et al (2009) Microbial degradation of cold-water coral-derived organic matter: potential implication for organic $\mathrm{C}$ cycling in the water column above Tisler reef. Aquatic Biol 7(1-2):71-80. https://doi.org/10.3354/ab00185

Wilkinson CR (1983) Net primary productivity in coral reef sponges. Science 219(4583):410-412

Wilkinson CR (1992) Symbiotic interactions between marine sponges and algae. In: Reisser W (ed) Algae and symbiosis: plants, animals, fungi, viruses. Interactions explored. Biopress, Bristol, pp 112-151

Wilson MC, Mori T, Rückert C et al (2014) An environmental bacterial taxon with a large and distinct metabolic repertoire. Nature 506:58-62

Witte U, Brattegard T, Graf G et al (1997) Particle capture and deposition by deep-sea sponges from the Norwegian-Greenland Sea. Mar Ecol Prog Ser 154:241-252

Wulff JL (1986) Variation in clone structure of fragmenting coral reef sponges. Biol J Linnean Soc 27:311-330. https://doi. org/10.1111/j.1095-8312.1986.tb01740.x

Zenkevich LA, Barsanova NG, Beliaev G (1960) Quantitative distribution of bottom fauna in the abyssal area of the World Ocean. Dokl Akad Nauk SSSR 130:183-186

Zundelevich A, Lazar B, Ilan M (2007) Chemical versus mechanical bioerosion of coral reefs by boring sponges - lessons from Pionecf. vastifica. J Exp Biol 210(1):91-96

Open Access This chapter is licensed under the terms of the Creative Commons Attribution 4.0 International License (http://creativecommons. org/licenses/by/4.0/), which permits use, sharing, adaptation, distribution and reproduction in any medium or format, as long as you give appropriate credit to the original author(s) and the source, provide a link to the Creative Commons license and indicate if changes were made.

The images or other third party material in this chapter are included in the chapter's Creative Commons license, unless indicated otherwise in a credit line to the material. If material is not included in the chapter's Creative Commons license and your intended use is not permitted by statutory regulation or exceeds the permitted use, you will need to obtain permission directly from the copyright holder. 